\title{
НОВЫЙ КЛАСС ПРОТИВОВИРУСНЫХ АЗОЛОАЗИНОВ
}

\author{
В.Л. Русинов ${ }^{1,2}$, В.Н. Чарушин ${ }^{1,2}$, О.Н. Чупахин ${ }^{1,2}$ \\ 1 Уральский федеральный университет имени первого Президента России \\ Б.Н. Ельцина, 620002, Россия, Екатеринбург, Мира, 19. \\ ${ }^{2}$ Институт органического синтеза имени И.Я. ПостовскогоУрО РАН, \\ 620041, Россия, Екатеринбург, ул. Софьи Ковалевской/Академическая, 22/20.
}

DOI: 10.19163/MedChemRussia2021-2021-10

E-mail:v.l.rusinov@urfu.ru

Найден новый оригинальный класс ненуклеозидных противовирусных этиотропных ве-ществ, эффективных в отношении заболеваний, вызываемых РНК-содержащими вирусами: гриппа, клещевого энцефалита, различных геморрагических лихорадок - нитроазоло[1,5-а]-пиримидины 1,2 и нитроазоло[5,1-с]1,2,4-триазины 3-5. Основные методы построения таких полиазотистых бициклических структур включают достройкуазинового цикла к азольному, что позволяет использоватьширокий круг аминоазолов 6 и доступных нитросинтонов 7-11.

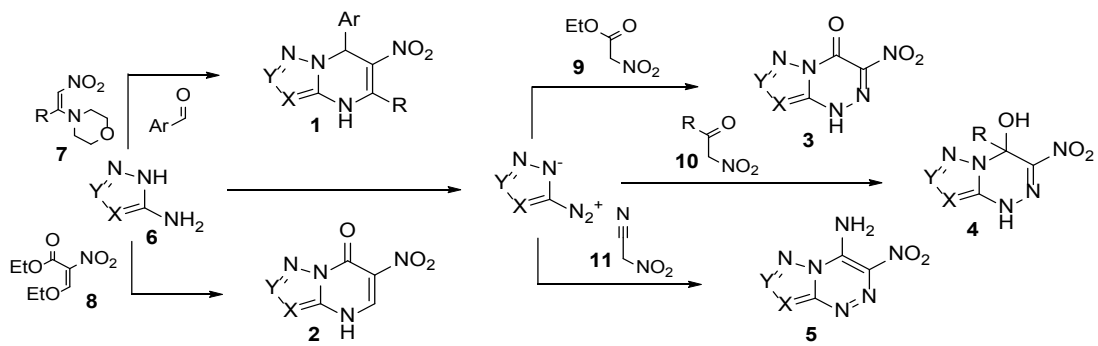

Полученные данные представляют реальную основу для создания серии эффективных отече-ственных противовирусных средств. Первый препарат, созданный на базе этого класса соединений, Триазавирин или Риамиловир (натриевая соль 2-метилтио-6-нитро-1,2,4-триазоло[5,1-с]-1,2,4-триазин-7-она, дигидрат), включен в реестр лекарственных средств РФ, № ЛП-002604. В ходе клиническогопримененияпоказано, что использование Триазавиринав этиотропной терапии гриппа, ОРВИ [1] и клещевого энцефалита [2] способствует сокращению продолжительности основных симптомов заболевания и значительному снижению уровня повторного выделения вирусов. Препарат имеет успешный опыт применения на базе ковидных госпиталей в качестве этиотропного средства при терапии коронавирусной инфекции, а также в качестве средства медикаментозной профилактики [3].

Работа выполнена при поддержке Министерства науки и высшего образования

Российской Федерации, Грант № 075-15-2020-777.

\section{Литература}

[1] Инфекционные болезни, 2017, 15, 25-32; Терапевтический архив, 2021, 92(12), 291-295.

[2] Экспериментальная и клиническая фармакология, 2018, 350, 25-32.

[3] Engineering, 2020, 6(10), 1185-1191; Терапевтический архив, 2021, 93(3), 291-295; 2021, 93(4), 435-439. 